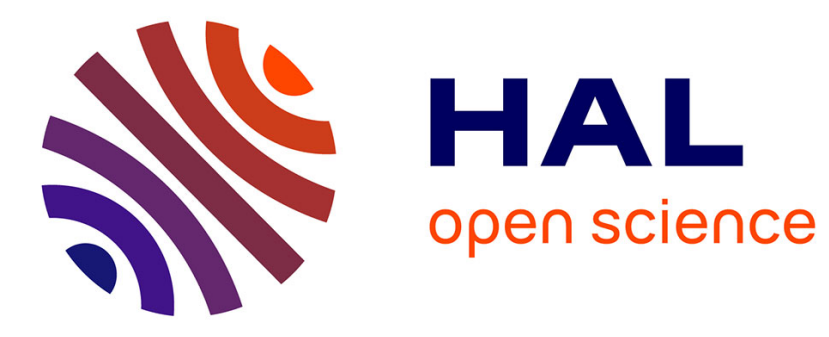

\title{
The actin cytoskeleton is involved in signalling protoplast embryogenesis induced by agarose embedding
}

Christian Brière, Henri Barthou, Alain Jauneau, Gilbert Alibert, Michel Petitprez

\section{- To cite this version:}

Christian Brière, Henri Barthou, Alain Jauneau, Gilbert Alibert, Michel Petitprez. The actin cytoskeleton is involved in signalling protoplast embryogenesis induced by agarose embedding. Physiologia Plantarum, 2004, 122, pp.115-122. 10.1111/j.1399-3054.2004.00374.x . hal-00023081

\section{HAL Id: hal-00023081 \\ https://hal.science/hal-00023081}

Submitted on 20 Apr 2006

HAL is a multi-disciplinary open access archive for the deposit and dissemination of scientific research documents, whether they are published or not. The documents may come from teaching and research institutions in France or abroad, or from public or private research centers.
L'archive ouverte pluridisciplinaire HAL, est destinée au dépôt et à la diffusion de documents scientifiques de niveau recherche, publiés ou non, émanant des établissements d'enseignement et de recherche français ou étrangers, des laboratoires publics ou privés. 


\title{
The actin cytoskeleton is involved in signalling protoplast embryogenesis induced by agarose embedding
}

\author{
Christian Brière $^{\mathrm{a}, \mathrm{b}}$, Henri Barthou ${ }^{\mathrm{a}}$, Alain Jauneau ${ }^{\mathrm{c}}$, Gilbert Alibert ${ }^{\mathrm{a}}$ and Michel Petitprez ${ }^{\mathrm{a}}$ \\ ${ }^{a}$ Laboratoire de Biotechnologie et Amélioration des Plantes, INP-ENSAT, avenue de \\ l'Agrobiopole, Auzeville, F31326 Castanet Tolosan Cedex, France \\ ${ }^{\mathrm{b}}$ UMR CNRS 5546, Pôle de Biotechnologie Végétale, 18 chemin de Borde Rouge, Auzeville \\ F31326 Castanet-Tolosan, France \\ ${ }^{\mathrm{c}}$ IFR FR40, Pôle de Biotechnologie Végétale, 18 chemin de Borde Rouge, Auzeville F31326 \\ Castanet-tolosan, France
}

\begin{abstract}
:
The organization of actin microfilaments was studied by immunofluorescence in protoplasts isolated from sunflower hypocotyls and cultured in an agarose matrix. Removal of the cell wall completely disrupted the actin cytoskeleton, which became progressively reorganized into cortical microfilament arrays and actin cables during protoplast culture. Treatment of protoplasts with Arg-Gly-Asp motif-containing peptides, to inhibit putative cell contacts with the agarose matrix, strongly affected this repair process: microfilament elongation and cable formation were inhibited and the connectivity between the cortical network and the perinuclear basket was lost. Furthermore, embryoid formation induced by agarose embedding was reduced. Similar effects were observed with a short treatment with latrunculin B, known to disrupt actin microfilaments. These results indicate that the actin network is involved in the signalling process that leads to polarity acquisition and embryoid determination in agaroseembedded protoplasts.
\end{abstract}

Keywords: actin, adhesion, cytoskeleton, protoplast, sunflower, Helianthus annuus 


\section{Introduction}

In Helianthus annuus (Chanabé et al. 1991; Krasnyanski and Menczel 1993; Alibert et al. 1994) as in Arabidopsis thaliana (O'Neill and Mathias 1993) inclusion of protoplasts in a solid matrix induces changes in their division mode and development pathways. In sunflower, protoplasts cultured in liquid medium divide symmetrically and form loosely associated colonies, whereas protoplasts embedded in agarose divide mostly asymmetrically, giving rise to compact embryo-like structures (Petitprez et al. 1995). It has been shown that i) the agarose matrix stabilizes the microtubule cytoskeleton (Caumont et al. 1997), ii) embryoid formation is mediated by contact between the agarose matrix and the cell surface (Barthou et al. 1999). These data strongly suggest the existence of trans-membrane proteins ensuring the linkage between the extracellular matrix and the cortical cytoskeleton.

In animal cells, the existence of such proteins is well known, the most prominent and beststudied matrix receptors belonging to the integrin family (Hynes 1992). In plant cells, although clear evidence is still lacking concerning the existence of such components (Pont Lezica et al. 1993; Reuzeau and Pont-Lezica 1995), several studies have shown that integrinlike proteins are present in Arabidopsis, Allium and Chara (Gens et al. 1996; Katembe et al. 1997) but whether they actually are integrins remains to be proved.

Numerous studies have focused on the role of the Arg-Gly-Asp (RGD) motif, known to mediate the interaction between integrin and its ligands (vitronectin or fibronectin) in animal cells (Haas and Plow 1994). A synthetic peptide bearing the RGD motif prevents plant cell growth (Schindler et al. 1989), protoplast adhesion (Zhu et al. 1993; Canut et al. 1998), embryoid differentiation in sunflower protoplasts (Barthou et al. 1999), and membrane-wall adhesion in Pelvetia (Henry et al. 1996). RGD dependent plasmalemma-cell wall interactions have also been implicated in plant defence response (Kiba et al. 1998; Mellersh and Heath 2001). Taken together, these data strongly suggest that membrane-extracellular matrix binding sites forward extracellular signals into the cell possibly via the cytoskeleton.

In sunflower protoplasts, previous studies have shown the role of the microtubule cytoskeleton in adhesion-signal transduction leading to a shift in protoplast developmental program resulting in embryoid differentiation (Caumont et al. 1997; Barthou et al. 1999). We report here on the involvement of actin in this signal transduction pathway. We show that disrupting actin microfilament arrays by actin drugs or by RGD motif containing peptides prevents or inhibits embryoid development.

\section{Material and Methods}

\section{Protoplast isolation and culture}

Seeds of Helianthus annuus L. var. Emil (Pioneer Hibred International) were cultured as described by Chanabé et al. (1989). Hypocotyls of seven-day-old seedlings were used for isolation of protoplasts which were cultured at a final density of $5 \times 10^{4} \mathrm{~mL}^{-1}$ in L4 medium (Lénée and Chupeau 1986) containing $14.6 \mathrm{mM}$ sucrose, $16 \mu \mathrm{M}$ 1-naphthalene acetic acid, 4. $4 \mu \mathrm{M}$ N6-benzyl aminopurin and $0.45 \mu \mathrm{M}$ 2,4-dichlorophenoxy acetic acid (TLD medium). Protoplasts were then embedded in $0.5 \%(\mathrm{w} / \mathrm{v})$ low-melting-point agarose (Sea plaque, FMC Bioproducts, Rockland, ME, USA) and solidified into $250 \mu \mathrm{L}$ droplets which were submerged in TLD medium according to Chanabé et al. (1991). Cultures were maintained at $25^{\circ} \mathrm{C}$ in the dark. The plating efficiency (= percent of divided protoplasts) was assessed at day 7. At day 10 , cultures were transferred to the light $\left(25 \mu \mathrm{E} \mathrm{m}^{-2} \mathrm{~s}^{-1}, 16 \mathrm{~h}\right.$ illumination) and the number of microcolonies and embryoids counted at day 21. Embryoid formation was expressed as the 
ratio between the number of embryoids and the total number of microcolonies (embryoid + loose colonies).

For immunofluorescence studies protoplasts were embedded in $0.5 \%(\mathrm{w} / \mathrm{v})$ agarose layers spread onto coverslips previously coated with Poly-L-Lysine (Sigma), submerged in TLD medium, and cultured in the same conditions.

\section{Effect of RGD peptides}

Hexapeptides GRGDSP and GDGRSP (5mM stock solution in water) were from Calbiochem (Meudon, France). Hexapeptide GRGDSP (final concentration $40 \mu \mathrm{M}$ ) was added to the culture medium immediately after protoplast embedding. Controls were performed by adding the GDGRSP peptide in the same conditions.

\section{Effect of cytoskeleton drugs}

Phalloidin (10mM stock solution in ethanol) and Latrunculin B (1mM stock solution in DMSO) were from Calbiochem (Meudon, France). 3-day old protoplasts, cultured in liquid TLD medium, were incubated in the presence of these drugs for $6 \mathrm{~h}$, either before or immediately after protoplast inclusion in agarose. They were then rinsed in TLD and the culture continued in standard conditions.

\section{Indirect immunofluorescence}

Protoplasts on coverslips were fixed for $1 \mathrm{~h}$ in $2 \%(\mathrm{w} / \mathrm{v})$ paraformaldehyde and $0.03 \%(\mathrm{w} / \mathrm{v})$ glutaraldehyde in microtubule stabilizing buffer (MSB) containing $50 \mathrm{mM}$ piperazine-N,N'bis (2-ethanesulfonic acid), $5 \mathrm{mM}$ ethylene glycol-bis ( $\beta$-aminoethylether) N,N'-tetraacetic acid (EGTA), $5 \mathrm{mM} \mathrm{MgSO}$, 0.08\% Nonidet P40, pH 6.9 (Traas et al. 1989). Fixed protoplasts were treated with Triton X-100 $(0.25 \%$, v/v, in MSB) for $30 \mathrm{~min}$ to increase membrane permeability. To reduce aldehyde-induced fluorescence, samples were treated 3 times $10 \mathrm{~min}$ with $10 \mathrm{mM} \mathrm{NaBH}_{4}$ in $10 \mathrm{mM}$ phosphate buffer saline, $\mathrm{pH} 8$, rinsed twice in TBS-Mg (10mM Tris buffer saline, $\left.30 \mathrm{mM} \mathrm{MgCl}_{2}, \mathrm{pH} 7.6\right)$ and treated with $5 \%(\mathrm{w} / \mathrm{v})$ normal goat serum in the same buffer for $30 \mathrm{~min}$. Protoplasts were incubated overnight at $25^{\circ} \mathrm{C}$ with N350 mouse monoclonal anti F-Actin (Amersham, UK) diluted 250 fold in TBS-Mg. They were rinsed twice in TBS-Mg, once in $0.1 \%(\mathrm{w} / \mathrm{v})$ bovine serum albumin dissolved in TBS$\mathrm{Mg}$ (TBS-BSA) and further incubated for $2 \mathrm{~h}$ with fluorescein isothiocyanate (FITC)conjugated sheep anti-mouse immunoglobulin antibody (Amersham), diluted 1/50 in TBSBSA. After one wash in the same buffer, coverslips were mounted on slides in antifading medium Citifluor (Link analytical, Oxford).

\section{Microscopy observation}

Plating efficiency: protoplasts in culture were observed on an inverted microscope (Leica, Heidelberg, Germany). For each plate a minimum number of 100 objects was counted, and the type of cell (divided or undivided), or the type of microcolony (loose colony or embryoid) were scored to determine the plating efficiency.

Actin pattern: immunolabelled protoplasts were examined with a Leitz epifluorescence microscope equipped with excitation and barrier filters BP450-490/BP520-525. Photographs were taken with a Wild MPS51S camera and a Fujichrome 400 film for colour slides. Protoplasts were scored according to the characteristics of the actin pattern: type of filaments (only dots or patches, short filaments, or presence of long filaments), type of organization (parallel or random) of actin arrays (when present), and presence of actin wires. 


\section{Quantitative image analysis of actin labelling}

Due to the fixation process, many protoplasts did not keep a spherical shape, but were flattened. This had the advantage of allowing the observation of large parts of the cytoskeleton network without changing the focus. These flattened protoplasts on which measurements of filament length was possible were thus used for quantitative imaging.

A DMIRBE inverted microscope (Leica) equipped for epifluorescence illumination and a Color Coolview camera (Photonic Science, UK) were used for image acquisition and digitisation. Fluorescence images (512x512 pixels, 8 bits depth, pixel size $310 \mathrm{~nm}$ ) were recorded with a PL APO 40X oil immersion objective (NA 1.25) and with a BP 450-490 nm excitation filter and an LP $515 \mathrm{~nm}$ emission filter (Leica). For each experimental condition digital images of 50 protoplasts were recorded and analysed with Image-Pro Plus image processing software (Media Cybernetics, Maryland, USA). After background subtraction, each image was segmented by binarization, the threshold being manually adjusted to eliminate the background noise outside the protoplast. Two morphological filters were then applied to the resulting binary image: a thinning filter followed by a dilatation filter to further reduce the noise. The lengths of segmented objects were then assessed by the software. For every cell, the number of segments, the maximum length and the total length were recorded. For each condition, the figures represent the average of all these values for the whole number of protoplasts measured.

The fixation process of protoplasts may lead to underestimate the maximum length of filaments, due to possible folding or breakdown of long filaments, and thus to underestimate differences between culture conditions. But this will have no effect on conclusions drawn from statistical tests showing significant differences of length between different culture conditions.

\section{Statistics}

The division frequency at day 7 was calculated as follows: division frequency $(\%)=100 \mathrm{x}$ number of divided protoplasts / number of observed protoplasts. At day 21, embryoid frequency $(\%)=100 \mathrm{x}$ number of embryoids / number of (embryoids + loose colonies). The values are the means of 3 to 5 experiments in which 700 to 2100 protoplasts and 50 to 385 embryoids were respectively observed at day 7 and day 21 . Percent data were normalized by using $\operatorname{Arcsin} \sqrt{\%}$ transformation before comparison with Student's t-test.

Distributions of actin patterns in control and treated protoplasts were compared with the $\chi^{2}$ test.

\section{Results}

Actin network dynamics in control protoplasts

The dynamics of the actin network in protoplasts was followed by immunofluorescence from day 0 to day 6 in culture. For each protoplast the overall organization of actin labelling was observed and sorted into different categories (Fig. 1). Freshly isolated protoplasts (i.e. observed about 1 hour after inclusion in agarose) showed no filamentous actin but only punctuated labelling all over the cell surface and perinuclear labelling (Fig. 1A1). Rapidly, within the first day of culture, short microfilaments (MFs) formed and extended through the whole protoplast cortex (Fig 1B1): after $6 \mathrm{~h}, 32 \%$ of the protoplasts showed a punctate pattern, $53 \%$ showed short MFs, whereas only 15\% had long MFs (Fig. 1A2-C2). The proportion of protoplasts with long MFs (Fig. 1C1) increased progressively during the culture, exceeding $60 \%$ after 48 hours. In a few protoplasts these long MFs appeared to form a parallel array 
(Fig. 1D1). This parallel organization was observed in an increasing number of protoplasts with time but never concerned more than $20 \%$ of the protoplasts (Fig. 1D2). Beside this cortical MF network, the perinuclear basket of MFs appeared to be progressively connected to the cortical network by cytoplasmic actin wires (Fig.1E1) which started to appear during the first 3 days of culture and were observed in more than $80 \%$ of 5-day-old protoplasts (Fig. 1E2).

In order to quantify the appearance of the cortical actin network, fluorescence images of protoplasts were analysed numerically and three parameters were assessed: the number of filaments, the maximum length of a filament, and the total length of the network in a protoplast (Fig. 2, empty bars). The number of filaments depends on the number of nucleation sites whereas their length reflects the elongation activity. In freshly isolated protoplasts the number of actin segments was low (108 at 6h) and increased gradually with time, up to 296 at $144 \mathrm{~h}$ (Fig2A). At the same time, the maximum length of microfilaments increased from $20 \mu \mathrm{m}$ to $70 \mu \mathrm{m}$ (Fig2B) and the total length of the actin network increased from $200 \mu \mathrm{m}$ to $500 \mu \mathrm{m}$ (Fig.2C). These data reveal an intense activity of actin nucleation and microfilament elongation in cultured protoplasts.

\section{$R G D$ peptide inhibits embryoid formation and affects actin microfilament organization}

To inhibit cell contacts with the agarose matrix, the hexapeptide GRGDSP, bearing the RGD motif, was added to the culture medium either immediately after protoplast inclusion or after 1 to 4 days of culture. The GDGRSP peptide was used in control experiments. At day 21 microcolonies (Fig. 3A) and embryoids (Fig. 3B) were counted. As shown in Fig. 3C, a strong inhibition of embryoid formation was observed in RGD-treated protoplast cultures. A maximal effect was obtained when GRGDSP peptides were added between 48 and 96 hours of culture.

Protoplasts cultured for $24 \mathrm{~h}$ in the presence of the GRGDSP peptide displayed very short cortical microfilaments often restricted to actin dots (Fig. 4A), the cytoplasmic actin wires were often broken (Fig.4B) leaving the nucleus disconnected from the cortex (Fig. 4C). No such effect was observed in protoplasts treated with the GDGRSP peptide. For a better understanding of the effect of the RGD peptide on the organization of microfilaments, we assessed the proportions of protoplasts showing one of the three following actin structures: cortical actin dots, parallel cortical microfilaments, and cytoplasmic actin wires. In contrast to control experiments, the proportion of protoplasts showing actin dots decreased only slightly in RGD-treated cultures (Fig.5A), reaching $25 \%$ at $120 \mathrm{~h}$ against $0 \%$ in control cultures. On the contrary, parallel arrays of microfilaments, which appeared as early as the first day of culture in controls, were not observed before 48h in RGD-treated protoplasts (Fig. 5B). This delay in the cortical array organization was correlated with a marked reduction of the percentage of protoplasts exhibiting such a parallel cortical array. Finally assembly of cytoplasmic wires was also strongly inhibited by RGD peptides (Fig. 5C): at 120h, as compared to the control, less than half of the protoplasts possessed actin wires connecting the nucleus to the cortical array.

Actin microfilament dynamics were quantified by an image analysis approach (Fig.2, black bars). It can be observed that for the three parameters assessed (number of actin segments, max. length of actin filaments and total length of the actin array) after one day of culture the values of the assay were lower than in the control and the difference increased with time. This was particularly true for the length of the longest filament and for the total length of the actin network in 4 and 5-day-old protoplasts: they were significantly lower in RGD-treated protoplasts than in the control. Although the decrease of the network length may be partially explained by a decrease of the number of filaments, it is clear that there is a significant 
reduction of microfilament length. These results strongly suggest that RGD peptides mainly inhibit the actin microfilament elongation process.

\section{Involvement of the actin cytoskeleton in embryoid formation}

In order to study the involvement of actin microfilaments in the transduction of the matrixadhesion signal, protoplasts were treated with drugs known to stabilize - phalloidin - or depolymerise - latrunculin B - actin microfilaments (Gibbon et al. 1999; Mathur et al. 1999). In these experiments 3-day-old protoplasts cultured in liquid medium were used to ensure that before the treatment they had recovered a complete actin network. Furthermore, previous work (Caumont et al. 1997) has shown that, on average, less than $40 \%$ of the cell wall has been rebuild in 3-day-old protoplasts. Protoplasts were embedded in agarose and immediately incubated with the drugs for $6 \mathrm{~h}$ in order to allow connections between the cell membrane and the extracellular matrix to establish. Increasing concentrations of the drugs were used to determine the optimum concentrations. Then one sample was immediately fixed and immunolabelled with anti-actin, another sample was rinsed and cultured in standard conditions. The percentages of cell division and of embryoids were then assessed after 7 days and three weeks of culture, respectively.

Phalloidin did not modify the microfilament network up to $1 \mu \mathrm{M}$ as compared to the control. At $10 \mu \mathrm{M}$, a marked stabilizing effect was observed, nearly all protoplasts presenting long microfilaments and actin wires. The division rate and the proportion of embryoids were not modified by the treatment (Table 1). It clearly appears that whatever the concentration tested, including the $10 \mu \mathrm{M}$ stabilizing dose, phalloidin did not alter the protoplast division process.

Latrunculin B is a very potent actin-depolymerizing drug. We tested the effect of increasing concentrations of latrunculin $\mathrm{B}$, ranging from $10 \mathrm{nM}$ to $50 \mu \mathrm{M}$, on the organization of cortical actin MFs. At 10nM, cortical MFs were short, at 200nM cortical actin appeared both as short MFs and dots, at $1 \mu \mathrm{M}$ there were only cortical dots and many protoplasts were not stained by anti-actin antibody, and at $50 \mu \mathrm{M}$ there were no visible MFs and most of the protoplasts were unlabelled (Fig. 1F). Between 10nM and 200nM, no modification of the division rate was observed (Table 1). In contrast, embryoid differentiation was significantly reduced by about $30 \%$, but no clear dose-response relationship was found between the intensity of this effect and the tested concentrations. In control experiments with DMSO, the solvent alone was added at a final dilution (1:5000) corresponding to the concentration of solvent in $200 \mathrm{nM}$ latrunculin B treatments. No significant difference was observed between the proportion of embryoids in DMSO treated cultures $(24.3 \pm 1.7 \%)$ and in control cultures $(25.2 \pm 1.8 \%)$. Thus, the inhibition of embryoid differentiation observed in latrunculin B treated cultures cannot be explained by a solvent effect but is really due to an effect of the drug.

Similar results were observed when the drugs were applied for $6 \mathrm{~h}$ immediately before inclusion in agarose.

Taken together these results indicate that modification of the actin cytoskeleton at the time of protoplast inclusion contributes to determine embryoid differentiation.

\section{Discussion}

In sunflower protoplasts embedded in agarose the first division is asymmetric and leads to embryoid development, whereas in liquid medium the first division is symmetric, leading to the formation of loose microcolonies (Petitprez et al. 1995). An early marker of protoplast polarization is the migration of the nucleus from the cell centre towards the periphery of the protoplast. In Pelvetia and Micrasteria, actin microfilaments (MFs) and microtubules (MTs) have been associated with the migration of the nucleus towards the cortex (Meindl et al. 1994). In Fucus, it was suggested that actin-driven targeted secretions of sulphated compounds could fix the cell division axis (Brownlee and Bouget 1998). Moreover, in this 
latter model, the fixation of the first division axis requires linkage of MFs to the cell wall with the participation of putative transmembrane factors (Quatrano et al. 1991). In tobacco, the cell wall matrix is necessary for the positioning of the nucleus (Katsuta and Shibaoka 1988). All these results implicate the actin network in the cell fate: its connections, on one side with the extracellular matrix and on the other side with the peri-nuclear basket appear to be crucial to the initiation of cell polarity.

In our model, freshly prepared protoplasts exhibited complete disorganization of the actin network resulting from the digestion of the cell wall matrix as previously reported in Nicotiana (Rutten and Derksen 1990). Rapidly, the reconstruction of the actin network occurred and showed different patterns (as illustrated figure 1) which have been previously described in a wide variety of eukaryotic organisms (Clayton and Lloyd 1985; Karpova et al. 1998) and correspond to interphasic MF networks already reported in plant cells (Seagull et al. 1987; Traas et al. 1987). During the rebuilding of the actin network, two main phases were distinguished: i) an increase of actin dots, which likely corresponds to active nucleation and assembly of monomers, and ii) an increase of maximum and total lengths of filaments resulting from the elongation of actin microfilaments. We also observed the establishment of connectivity between the cortical actin network and the perinuclear basket by cytoplasmic actin wires. It has been suggested that these cables could act as tracks for intracellular trafficking (Stamnes 2002) along which material would be transported between the cortex and the nucleus and so could participate in the cell polarity (Reddy 2001). Whatever the exact mechanisms involved in the actin network reconstruction, protoplasts embedded in agarose are further able to divide in an asymmetric manner and to give rise to embryoids.

The application of latrunculin B or RGD peptides to agarose-embedded protoplast cultures reduced the formation of embryoids. Cable formation and MF elongation were also inhibited and connectivity between the cortical network and the perinuclear basket was not observed. The modification of cell fate through the application of RGD peptides has already been reported in maize where calli became more compact and displayed an effect similar to plasmolysis (Labouré et al. 1999). In Arabidopsis thaliana cells, RGD peptides were able to bind purified plasma membranes and to inhibit cell-cell adhesion (Canut et al. 1998). In sunflower protoplast, plasmolysis inhibited embryoid formation, as did RGD treatment (Barthou et al. 1999) suggesting that the association of the plasma membrane with the cell wall was involved in cell development. In plant cells, this association has been reported to be indispensable to maintain the stationary organisation of the MFs (Ryu et al. 1997) and of cortical microtubules (Akachi et al. 1990; Akachi and Shibaoka 1991). However, even if such adhesion sites have been demonstrated in our model (Caumont et al. 1997; Barthou et al. 1999), the protein components of adhesion complexes remain to be clearly identified. To date, only spectrin-like, integrin-like and vinculin-like epitopes have been evidenced (Wasteneys and Galway 2003), but none of these proteins have been clearly characterized in plant cells.

Overall, these results strongly suggest that in agarose-embedded protoplasts, a continuum occurs between the agarose extracellular matrix, the plasma membrane and the perinuclear basket via the actin MF network. Previous results have shown that the microtubule cytoskeleton is also involved in this continuum (Barthou et al. 1999). The early establishment of this continuum (before cell wall synthesis) appears to be essential for cell fate determination. In liquid media, where extracellular contacts are lacking, embryoids cannot develop. It is thus likely that agarose embedding of protoplasts allows the formation of transmembrane adhesion complexes that anchor the protoplast to this extracellular matrix and stabilize the cytoskeleton network. This would help to determine and/or fix the polarity of the cell leading to asymmetric division and embryoid development. In this report, we show that not only microtubules but also the actin cytoskeleton are involved in this signalling process. 
The nature of the adhesion complexes and their impact on microtubule and actin organization remain to be determined.

\section{Acknowledgements}

We thank Philippe Anson and Marie-Josée Tavella for their technical support in plant culture and protoplast preparation.

\section{References}

Akashi T, Kawasaki S, Shibaoka H (1990) Stabilization of cortical microtubules by the cell wall in cultured tobacco cells. Planta 182: 363-369

Akashi T, Shibaoka H (1991) Involvement of transmembrane proteins in the association of cortical microtubules with the plasma membrane in tobacco BY-2 cells. J Cell Sci 98: 169174

Alibert G, Aslane-Chanabe C, Burrus M (1994) Sunflower tissue and cell cultures and their use in biotechnology. Plant Physiol Bioch 32: 31-44

Barthou H, Petitprez M, Brière C, Souvré A, Alibert G (1999) RGD-mediated membranematrix adhesion triggers agarose-induced embryoid formation in sunflower protoplasts. Protoplasma 206: 143-151

Brownlee C, Bouget F, Y, (1998) Polarity determination in Fucus: From zygote to multicellular embryo. Semin Cell Dev Biol 9: 179-185

Canut H, Carrasco A, Galaud JP, Cassan C, Bouyssou H, Vita N, Ferrara P, Pont-Lezica R (1998) High-affinity RGD-binding sites at the plasma membrane of Arabidopsis thaliana links the cell wall. Plant J 16: 63-71

Caumont C, Petitprez M, Woynaroski S, Barthou H, Brière C, Kallerhoff J, Borin C, Souvré A, Alibert G (1997) Agarose embedding modifies cell-wall regeneration and microtubule organization in sunflower hypocotyl protoplasts. Physiol Plant 99: 129-134

Chanabé C, Burrus M, Alibert G (1989) Factors affecting the improvement of colony formation from sunflower protoplasts. Plant Sci 64: 125-132

Chanabé C, Burrus M, Bidney D, Alibert G (1991) Studies on plant regeneration from protoplasts in the genus Helianthus. Plant Cell Rep 9: 635-638

Clayton L, Lloyd C (1985) Actin organization during the cell cycle in meristematic plant cells. Exp Cell Res 156: 231-238

Gens JS, Reuzeau C, Doolittle KW, McNally JG, Pickard BG (1996) Covisualization by computational optical-sectioning microscopy of integrin and associated proteins at the cell membrane of living onion protoplasts. Protoplasma 194: 215-230

Gibbon BC, Kovar DR, Staiger CJ (1999) Latrunculin B has different effects on pollen germination and tube growth. Plant Cell 11:2349-2363

Haas TA, Plow EF (1994) Integrin-ligand interactions: a year in review. Curr Opin Cell Biol 6: 656-662

Henry CA, Jordan JR, Kropf DL (1996) Localized membrane-wall adhesions in Pelvetia zygotes. Protoplasma 190: 39-52

Hynes RO (1992) Integrins: versalility, modulation, and signaling in cell adhesion. Cell 69: $11-25$

Karpova TS, Mcnally JG, Moltz SL, Cooper JA (1998) Assembly and function of the actin cytoskeleton of yeast: Relationships between cables and patches. J Cell Biol 142: 1501-1517 
Katembe WJ, Swatzell LJ, Makaroff CA, Kiss JZ (1997) Immunolocalization of integrin-like proteins in Arabidopsis and Chara. Physiol Plant 99: 7-14

Katsuta J, Shibaoka H (1988) The roles of the cytoskeleton and the cell wall in nuclear positioning in tobacco BY-Z cells. Plant Cell Physiol 29(3): 403-413

Kiba A, Sugimoto M, Toyoda K, Ichinose Y, Yamada T, Shiraishi T (1998) Interaction between cell wall and plasma membrane via RGD motif is implicated in plant defense responses. Plant Cell Physiol 39: 1245-1249

Krasnyanski S, Menczel L (1993) Somatic embryogenesis and plant regeneration from hypocotyl protoplasts of sunflower (Helianthus annuus L.). Plant Cell Rep 12: 260-263

Labouré AM, Faik A, Mandaron P, Falconet D (1999) RGD-dependent growth of maize calluses and immunodetection of an integrin-like protein. FEBS Lett 442: 123-128

Lénée P, Chupeau Y (1986) Isolation and culture of sunflower protoplasts (Helianthus annuus L.): factors influencing the viability of cell colonies derived from protoplasts. Plant Sci 43: $69-75$

Mathur J, Spielhofer P, Kost B, Chua N (1999) The actin cytoskeleton is required to elaborate and maintain spatial patterning during trichome cell morphogenesis in Arabidopsis thaliana. Development 126: 5559-5568

Meindl U, Zhang D, Hepler PK (1994) Actin microfilaments are associated with the migrating nucleus and the cell cortex in the green alga Micrasterias. Studies on living cells. J Cell Sci 107: 1929-1934

Mellersh D, Heath M (2001) Plasma membrane-cell wall adhesion is required for expression of plant defence responses during fungal penetration. Plant Cell 13: 413-424.

O'Neill CM, Mathias RJ (1993) Regeneration of plants from protoplasts of Arabidopsis thaliana L. cv. Columbia (C24), via direct embryogenesis. J Exp Bot 44: 1579-1585

Petitprez M, Brière C, Borin C, Kallerhoff J, Souvré A, Alibert G (1995) Characterisation of protoplasts from hypocotyls of Helianthus annuus in relation to their tissue origin. Plant Cell Tiss Org Cult 41: 33-40

Pont Lezica RF, Mac Nally JG, Pickard BG (1993) Wall-to-membrane linkers in onion epidermis: some hypotheses. Plant Cell Environ 16: 117-123

Quatrano RS, Brian L, Aldridge J, Schultz T (1991) Polar axis fixation in Fucus zygotes: components of the cytoskeleton and extracellular matrix. Development Supp. 1: 11-16

Reddy A (2001) Molecular motors and their function in plants. Int Rev Cytol 204: 97-178

Reuzeau C, Pont-Lezica RF (1995) Comparing plant and animal extracellular matrixcytoskeleton connections - are they alike? Protoplasma 186: 113-121

Rutten TLM, Derksen J (1990) Organization of actin filaments in regenerating and outgrowing subprotoplasts from pollen tube of Nicotiana tabacum L. Planta 180: 471-479

Ryu J, Mizuno K, Takagi S, Nagai R (1997) Extracellular components implicated in the stationary organization of the actin cytoskeleton in mesophyll cells of Vallisneria. Plant Cell Physiol 38: 420-432

Schindler M, Meiners S, Cheresh D (1989) RGD-dependent linkage between plant cell wall and plasma membrane: consequences for growth. J Cell Biol 108: 1955-1965.

Seagull R, Falconer M, Weerdenburg C (1987) Microfilaments: dynamic arrays in higher plant cells. J Cell Biol 104: 995-1004

Stamnes M (2002) Regulating the actin cytoskeleton during vesicular transport. Curr Opin Cell Biol 14: 428-433

Traas JA, Doonan JH, Rawlins DJ, Shaw PJ, Watts J, Lloyd CW (1987) An actin network is present in the cytoplasm throughout the cell cycle of carrot cells and associates with the dividing nucleus. J Cell Biol 105: 387-395 
Traas JA, Burgain S, Dumas de Vaulx R (1989) The organization of the cytoskeleton during meiosis in eggplant (Solanum melongena (L.)): microtubules and F-actin are both necessary for coordinated meiotic division. J Cell Sci 92: 541-550

Wasteneys G, Galway M (2003) Remodelling the cytoskeleton for growth and form: an overview with some new views. Ann Rev Plant Biol 54: 691-722

Zhu J-K, Shi J, Singh U, Wyatt SE, Bressan RA, Hasegawa PM, Carpita NC (1993) Enrichment of vitronectin- and fibronectin-like proteins in $\mathrm{NaCl}$-adapted plant cells and evidence for their involvement in plasma membrane - cell wall adhesion. Plant J 3: 637-646

Table 1: Effect of phalloidin and latrunculin B on the division rate and embryoid formation in protoplast culture. 3-day-old protoplasts were treated for $6 \mathrm{~h}$ by phalloidin or latrunculin B immediately after agarose embedding and were next cultured in standard conditions. Division rate was assessed at day 7; proportion of embryoids was assessed at day 21 . Values are expressed as percentages of control experiments. Mean values \pm standard-errors from three measurements $($ control $=100)$.

\begin{tabular}{lllllll} 
& \multicolumn{2}{l}{ Phalloidin } & \multicolumn{3}{l}{ Latrunculin } \\
\cline { 2 - 7 } & $0.1 \mu \mathrm{M}$ & $1 \mu \mathrm{M}$ & $10 \mu \mathrm{M}$ & $10 \mathrm{nM}$ & $50 \mathrm{nM}$ & $200 \mathrm{nM}$ \\
\hline Cell divisions & $109.0 \pm 6$ & $112.0 \pm 3$ & $107 \pm 3$ & $109 \pm 1$ & $109 \pm 2$ & $99 \pm 2$ \\
\hline Embryoids & & & $111 \pm 7$ & $75 \pm 10$ & $63 \pm 2$ & $67 \pm 6$ \\
\hline
\end{tabular}



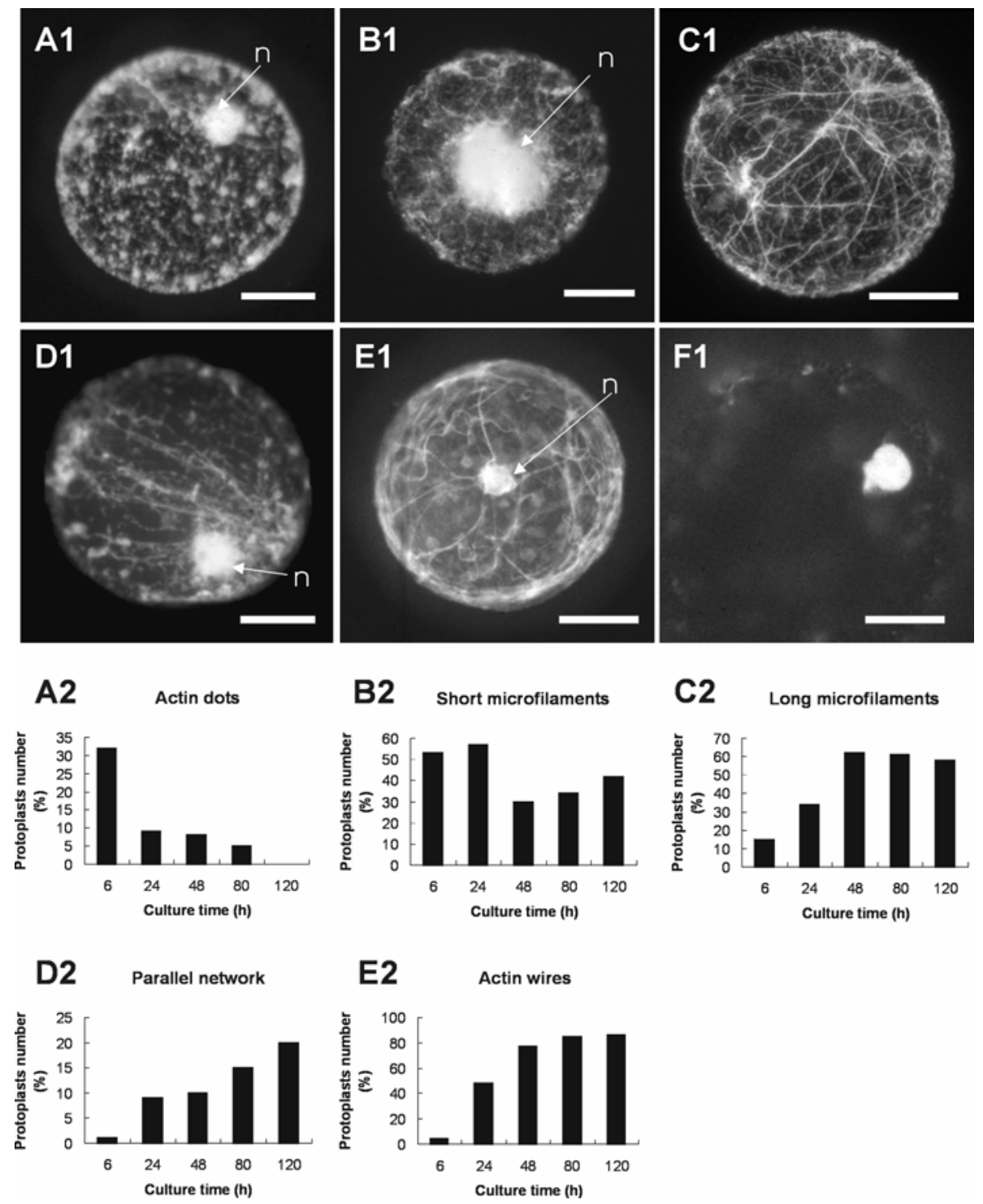

Fig.1: Actin patterns observed in sunflower protoplasts (A1 to E1) and frequency variations of these patterns (A2 to E2) during culture. (A) punctate dotted pattern of actin labelling, (B) short microfilaments, (C) random network of long microfilaments, (D) parallel network of actin microfilaments, and (E) actin wires connecting the nucleus to the cortex. (F) Absence of actin labelling in a protoplast treated with $50 \mu \mathrm{M}$ latrunculin B. $\mathrm{n}=$ nucleus, bar $=10 \mu \mathrm{m}$. Frequencies are based on the observation and scoring of 100 protoplasts, at each time. 

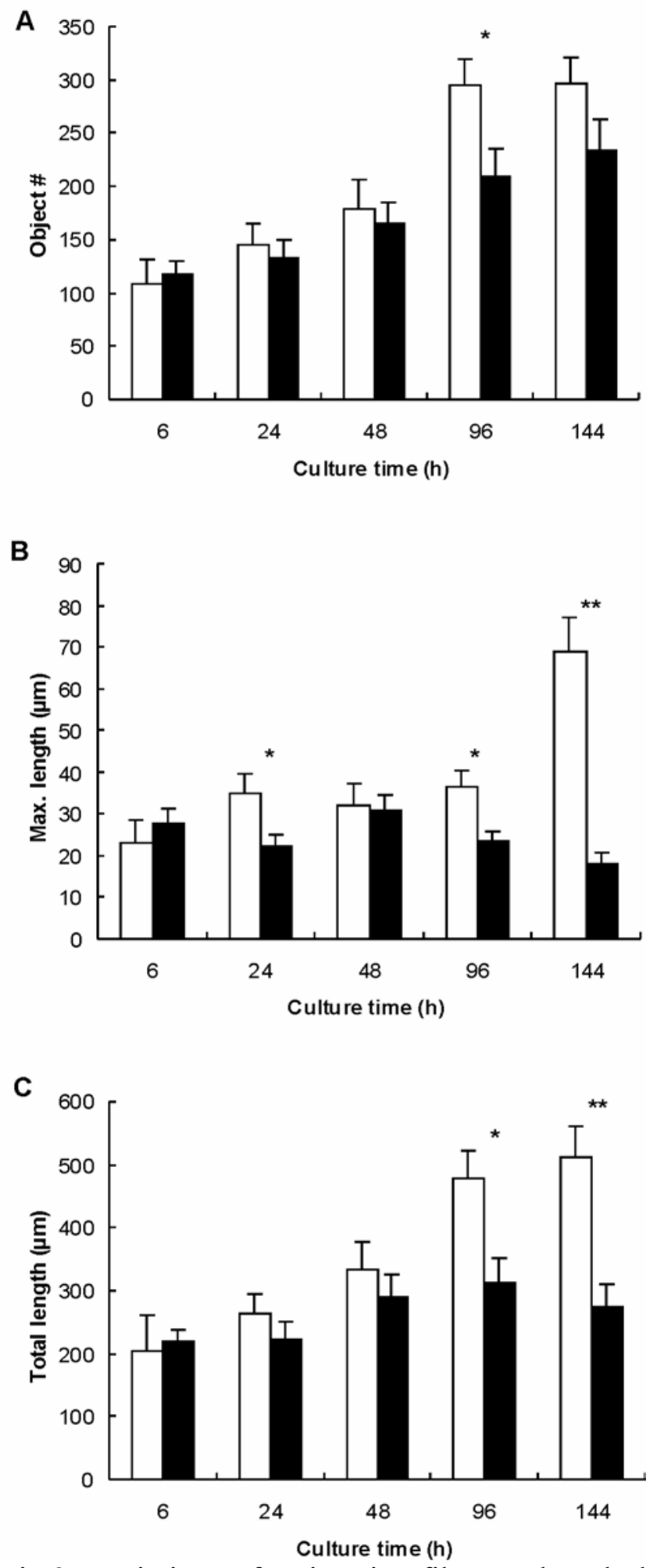

Fig.2: Variations of actin microfilament length during control (empty bars) and RGD-treated (black bars) protoplast culture. (A) Number of objects (dots or filaments) / protoplast, (B) maximum length, and $(\mathrm{C})$ total length of actin filaments per protoplast. Mean \pm S.E.M. from 13 (control) and 15 (RGD treatment) protoplasts. Treatments were compared with t-test: * $\mathrm{P}=0.05, * * \mathrm{P}=0.01$. Control $=$ protoplasts incubated with GDGRSP peptide. 

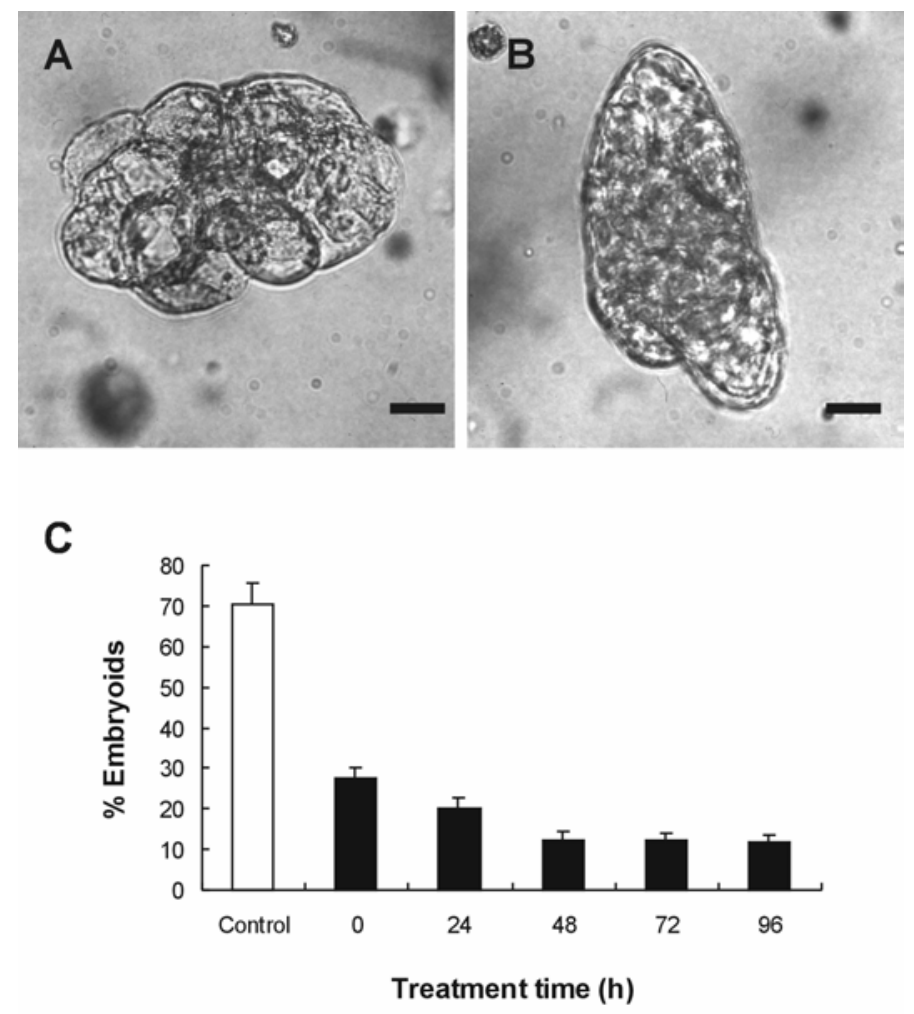

Fig. 3: Loose colony (A) and embryoid (B) observed in a 3-week-old culture of protoplasts embedded in agarose. Bar $=10 \mu \mathrm{m}(\mathrm{C})$ Effect of RGD peptides on embryoid formation: $100 \mu \mathrm{M}$ GRGDSP peptide was added to the culture medium either immediately after protoplast isolation and inclusion, or after different times of culture. Proportion of embryoids (= number of embryoid / total number of microcolonies) was assessed in 3-week-old cultures. Control $=$ protoplasts grown without addition of RGD peptides. The effect of the treatment was significant whatever the treatment time.
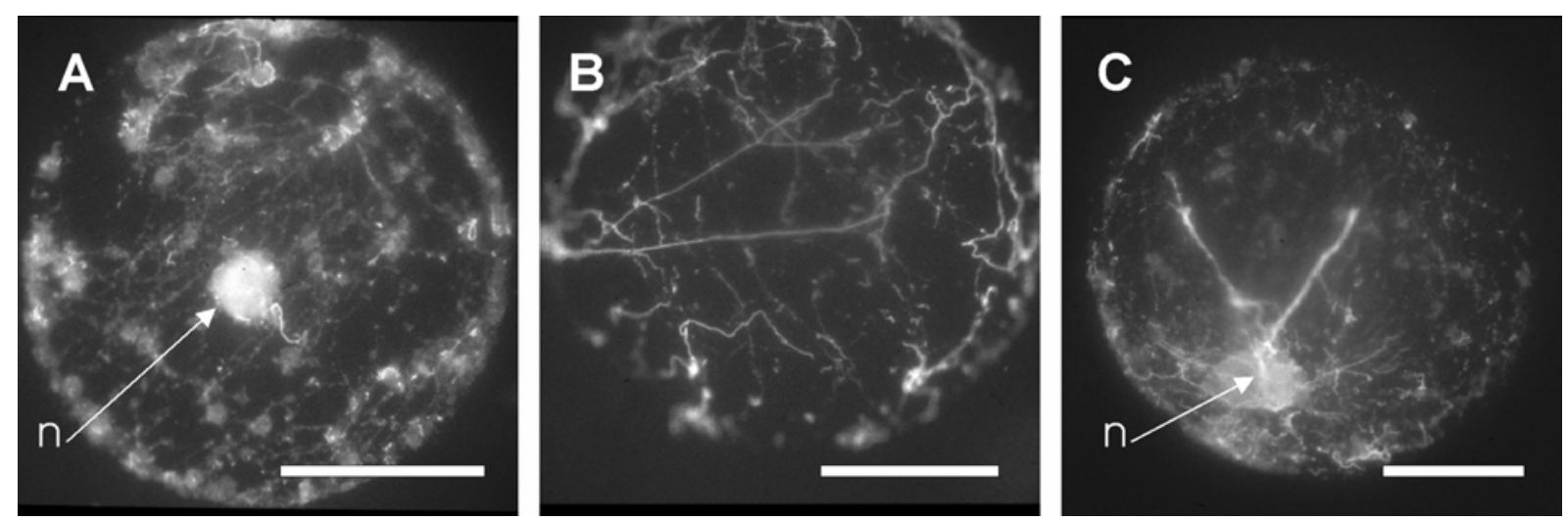

Fig. 4: Effect of RGD peptides on actin organization in 1-day-old protoplasts. Protoplasts incubated with the GRGDSP hexapeptide, showing (A) a disrupted cortical actin network, (B) and $(\mathrm{C})$ broken actin wires. $\mathrm{n}=$ nucleus, bar $=10 \mu \mathrm{m}$ 

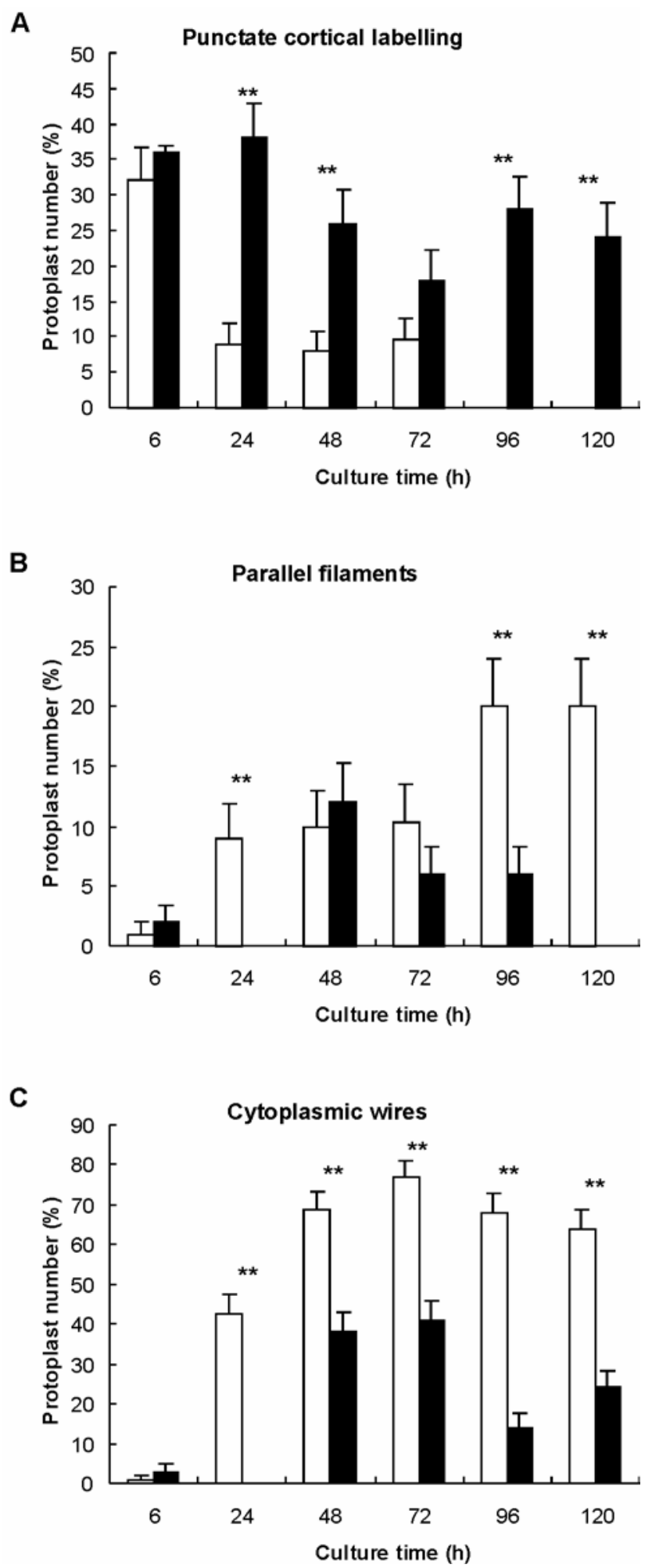

Fig. 5: Quantitative analysis of actin organization in RGD-treated protoplasts according to culture time. Treated protoplasts were incubated with the GRGDSP hexapeptide. Control protoplasts were incubated with the GDGRSP hexapeptide. (A) cortical actin dots, (B) cortical parallel microfilaments, $(\mathrm{C})$ cytoplasmic wires. Black bars $=$ RGD-treated, Empty bars $=$ control. Treatments were compared with $\chi^{2}$ test : ${ }^{*} \mathrm{P}=0.05, * * \mathrm{P}=0.01$ 